\title{
Methodology for assessing the integration of the Russian Federation into the world economy: the digital aspect
}

\author{
Konstantin B. Kostin
}

Saint-Petersburg State University of Economics, St. Petersburg, Russia

Anastasia A. Berezovska

Saint-Petersburg State University of Economics, St. Petersburg, Russia

\begin{abstract}
This study examines the development and functioning of e-business as a tool for integrating the country into the world economy. The article defines the basic concepts of integration, identifies the role of e-business in this process. The method of evaluation of e-business efficiency using the "AAB index" (where: $a=$ attractive, a $=$ artificial, $b=$ business) is proposed, including a system of such Indexes as financial stability, investment attractiveness, level of integration and competitiveness, as well as specialized Indexes of e-business and level of their reference values. The place of the Russian Federation in the world economy has been analysed using existing methods of assessment of integration. On the basis of our proposed method of assessing the integration of the country into the world economy, a comparison of the level of integration of the Russian Federation for 2016-2017 years was made. Directions of increasing the degree of integration of the country into the world economy due to optimization of electronic business are proposed. The analysis was performed based on the data of Russian companies operating in an electronic environment.
\end{abstract}

\section{Keywords}

Integration, world economy, e-business, efficiency of e-business, international company, digital economy, AAB index.

\section{Introduction}

Interest in analyzing and studying the peculiarities of integration processes in the world economy in Soviet economic literature arose in the 1950s. The impetus was the intensification of integration processes in Europe. As cooperation developed within the framework of the Council for Mutual Economic Assistance (hereinafter referred to as SMEA), the category "economic integration" marked a developed form of cooperative interaction between its participating States.

Foreign economic thought provides a deeper interpretation of economic integration. Emergence of the early special studies on this subject is dated in the 1930s. During the post-war period and furthermore in modern conditions, consideration of process of integration is considered from positions of theories of firm and institutionalism (Pazizina \& Uniyat, 2011). The main approaches to the interpretation of the term "integration" are grouped in Table 1. 
Table 1 Overview of basic approaches to the causes and nature of integration within the interim approach

\begin{tabular}{|c|c|c|c|}
\hline Period & $\begin{array}{l}\text { Characte-ristics of } \\
\text { theoretical approach }\end{array}$ & Understanding the reasons and nature of integration & $\begin{array}{l}\text { Main representatives of the } \\
\text { theoretical approach }\end{array}$ \\
\hline \multirow[t]{5}{*}{$\begin{array}{l}1960- \\
1990\end{array}$} & $\begin{array}{l}\text { Traditio-nal, technolo- } \\
\text { gical }\end{array}$ & $\begin{array}{l}\text { The driving force of integration is the desire to save on scale, } \\
\text { reduce entrance barriers, etc. }\end{array}$ & $\begin{array}{lrll}\text { R. Bork, } & \text { R. } & \text { Blair, } & \text { D. } \\
\text { Caserman. }\end{array}$ \\
\hline & $\begin{array}{l}\text { Transa-ction, modern } \\
\text { economic }\end{array}$ & $\begin{array}{l}\text { Integration takes place through the formation of significant } \\
\text { industrial and production complexes, which deny the } \\
\text { commodity and cost side of the exchange of labor results. }\end{array}$ & $\begin{array}{l}\text { R. Coose, O. I. Williamson, D. } \\
\text { North, K. Errow, and others } \\
\text { from the neo-institutional } \\
\text { school, authors of the theory of } \\
\text { "transactional economics." }\end{array}$ \\
\hline & Vertical integra-tion & $\begin{array}{l}\text { Economic linkages that reduce transaction costs are a } \\
\text { priority for integration. The advantages of integration include } \\
\text { harmonization of goals and interests, risk reduction, cost } \\
\text { savings to eliminate asymmetric information. }\end{array}$ & O.I. Williamson \\
\hline & $\begin{array}{l}\text { Liberal and illiberal } \\
\text { (market school) }\end{array}$ & $\begin{array}{l}\text { The integration process is based on exchange and trade. } \\
\text { Integration is a condition for ensuring free trade within the } \\
\text { integration grouping. Freedom of trade is achieved through } \\
\text { tariff and non-tariff regulation of the common trade area. }\end{array}$ & V. Repke, J. Rueff, R. Aron \\
\hline & $\begin{array}{l}\text { Market-instituti-onal } \\
\text { (neolibe-ral school) }\end{array}$ & $\begin{array}{l}\text { The development of economic integration is taking place in a } \\
\text { close relationship between public regulation and the market. }\end{array}$ & B. Balassa Allé, J. Weier \\
\hline $\begin{array}{l}\text { Mid- } \\
1960 \text { s }\end{array}$ & Structural & $\begin{array}{l}\text { Integration ensures the social development of the } \\
\text { participating countries: increases social equality, eliminates } \\
\text { imbalances in territorial development, and contributes to the } \\
\text { growth of the living standards and quality of life. }\end{array}$ & $\begin{array}{l}\text { G. Murray, A. Marshall, C. } \\
\text { Kindleberger, et al. }\end{array}$ \\
\hline \multirow[t]{3}{*}{ 1970s } & Neo-Keynesian & $\begin{array}{l}\text { In order to maximize the benefits of integration and maintain } \\
\text { economic sovereignty, coordination of the public policies of } \\
\text { the participating countries is necessary. }\end{array}$ & R. Cooper, B. F. Massel, et al. \\
\hline & Conduct-ing & $\begin{array}{l}\text { The conductor school reduces the integration process to the } \\
\text { harmonization of the social and economic policies of the } \\
\text { participating countries. Preference was given mainly to } \\
\text { factors of social development. }\end{array}$ & $\begin{array}{l}\text { J. Tinbergen, R. Sanwald, I. } \\
\text { Stoller }\end{array}$ \\
\hline & Functio-nal & $\begin{array}{l}\text { At the final stage of the integration process, a functional } \\
\text { system is formed, the individual elements of which do not } \\
\text { need common political structures. } \\
\text { The end product of integration is the formation of a functional } \\
\text { system, elements of which can start functioning without a } \\
\text { common political add-on. }\end{array}$ & D. Mitrani, L. Wolf, P. Rainsha \\
\hline $\begin{array}{l}1960- \\
1970 .\end{array}$ & Neofun-ctionalism & $\begin{array}{l}\text { The concept of "community" is a kind of "community or even } \\
\text { a system with self-sufficient integration mechanisms," while } \\
\text { "integration" is a kind of "ability of a given system to sustain } \\
\text { itself as a result of the impact and influence of both internal } \\
\text { and external changes." }\end{array}$ & $\begin{array}{l}\text { E. Haas, L. Lindbergh, A. } \\
\text { Etzoni }\end{array}$ \\
\hline
\end{tabular}

At present stage, integration within the EU is characterized by processes of its deepening and expansion. Successive stages of EU enlargement marked the emergence of a number of theoretical models of European integration. The most famous of these are the "strong core" model by V. Stoyble (Kaveshnikov, 2009); the "confederation" model of ex-President F. Mitterrand of France; The "central group" model; J. Delor's model of "concentric circles" (Rosamond, 2000). The Europe of two speeds - Merkel's attempt to save the EU model and many others (Hoffman \& Gurkov, 2017). In its majority, modern theoretical models of integration correspond to the global trends of regionalism of the world economy.
Some clarity should be given to the concepts of "regionalism" and "regionalization." Regionalism is a state "integration" policy. In contrast, "regionalization" is a process of "bottom-up integration," expressed mainly through the transnationalization of world and national economies and international economic relations. The process of regionalization includes a sufficiently strong "informal component," which is reflected in the emergence of geographical, social or cultural convergence between countries, civil society structures and new institutions that set the vector for integration processes (Philosophy of the integrations, 2011). 
On the basis of foreign studies' analysis, it was found that the main basic features of integration, characterizing its internal content and content, could include:

- Integration (internal form of economic association dominated by power structures);

- Conscious voluntary cooperation, the process of close cooperation generated at the intra-firm level, is more contrary to the market mechanism. This type of integration is based on the harmonization of common development goals and the awareness of the participants in the integration process of the necessity and effectiveness of combining their joint efforts.

- Quality of management plays a crucial role in building successful integration.

As a result, it can be concluded that integration in the economic plane is a particularly complex form of division of labor and social production, which arises and develops in modern conditions of NTR and increasingly active application of intellectual capital.

\section{Key indexes of electronic business efficiency}

At present, there is practically no common normative methodology in the scientific literature for assessing the level of international economic integration of the national economy into the world economy. To a greater extent, the available methods make it possible to assess the level of development of export potential of the national economy, efficiency of foreign economic activity, to assess the level of migration of its labor force and capital. At the same time, they do not fully reflect the full depth of the problems of international integration of countries into the world economy and do not take into account the impact of the degree of development of e-business on the integration process. The algorithm for assessing the integration of the country into the world economy is shown in Figure 1.
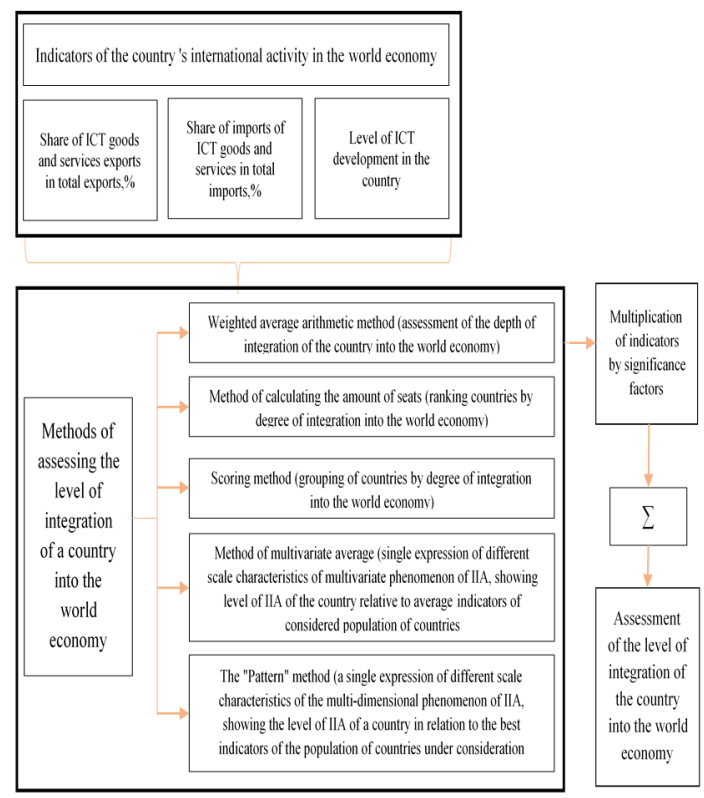

Figure 1 Algorithm for assessing the country's integration into the world economy

Source: compiled by the authors based on materials of Goreckaya \& Kosulina, 2011

The methodology we propose takes into account a wider range of integration problems based on the characteristics of the transition period as a result of the change of technological patterns. The evaluation will be carried out through an analysis of the indicator framework based on existing methods. The proposed methodology for assessing a country's integration into the world economy involves the use of a framework of indicators (table 2). The indicators in the table are for the information and communications technology sector (see for examples: Hyers, D., and Kovacova, M., 2018), which is fundamental to e-business because the latter is based on the use of these technologies.

Table 2 Indicators on how to measure a country's integration into the world economy in relation to the ICT

\begin{tabular}{|l|l|l|}
\hline Integration indicator & variable & Unit of measure \\
\hline $\begin{array}{l}\text { Level of ICT development in } \\
\text { the country (ICT } \\
\text { Development Index) }\end{array}$ & X1 & point \\
\hline $\begin{array}{l}\text { Exports of ICT-related } \\
\text { goods and services }\end{array}$ & X2 & $\begin{array}{l}\text { \% of total exports of } \\
\text { goods and services }\end{array}$ \\
\hline $\begin{array}{l}\text { Imports of ICT-related } \\
\text { goods }\end{array}$ & X3 & $\begin{array}{l}\text { \% of total imports of } \\
\text { goods and services }\end{array}$ \\
\hline
\end{tabular}

Source: The authors

The classification characteristics of a country's integration into the world economy were selected by the economic degree of integration of ICT into the world economy. Table 3 provides an analysis 
of the countries on which their integration into the world economy will be assessed. The countries selected for analysis are the leaders of the ebusiness market in the level of revenue generated by e-business and the level of readiness of these countries for the information economy is highest.

On the basis of the obtained data, we will assess the level of integration of the Russian Federation into the world economy in terms of the ICT sector, which is fundamental for e-business.

Table 3 Data for calculation of the level of integration of countries into the world economy, 2017

\begin{tabular}{|c|c|c|c|}
\hline Country & $\begin{array}{l}\text { ICT Development } \\
\text { Index, X1 } \\
\text { (Information } \\
\text { Society Report } \\
\text { 2017) }\end{array}$ & $\begin{array}{l}\text { Share of ICT } \\
\text { goods and } \\
\text { services in } \\
\text { total exports, } \\
\text { X2,\% (Official } \\
\text { website of the } \\
\text { World Bank) }\end{array}$ & $\begin{array}{c}\text { Share of } \\
\text { information and } \\
\text { communication } \\
\text { technology } \\
\text { products in total } \\
\text { imports, X3 } \\
\text { (Official website of } \\
\text { the World Bank) }\end{array}$ \\
\hline Iceland & 8.98 & 2.757 & 3.484 \\
\hline Korea, Rep. & 8.85 & 22.071 & 11.818 \\
\hline Switzerland & 8.74 & 3.857 & 2.816 \\
\hline Denmark & 8.71 & 4.946 & 4.561 \\
\hline $\begin{array}{c}\text { United } \\
\text { Kingdom }\end{array}$ & 8.65 & 5.66 & 5.764 \\
\hline Netherlands & 8.49 & 10.69 & 10.28 \\
\hline Luxembourg & 8.47 & 3.588 & 1.006 \\
\hline Norway & 8.47 & 2.369 & 4.032 \\
\hline Japan & 8.43 & 7.145 & 10.012 \\
\hline Sweden & 8.41 & 10.128 & 6.356 \\
\hline Germany & 8.39 & 6.199 & 6.733 \\
\hline New Zealand & 8.33 & 1.807 & 5.688 \\
\hline Australia & 8.24 & 1.813 & 7.288 \\
\hline France & 8.24 & 4.839 & 4.634 \\
\hline United States & 8.18 & 8.063 & 11.608 \\
\hline Estonia & 8.14 & 9.697 & 7.105 \\
\hline Singapore & 8.05 & 24.343 & 17.562 \\
\hline Austria & 8.02 & 5.371 & 3.858 \\
\hline Ireland & 8.02 & 24.138 & 2.429 \\
\hline Finland & 7.88 & 9.929 & 4.793 \\
\hline Israel & 7.88 & 25.517 & 6.301 \\
\hline Spain & 7.79 & 3.815 & 3.964 \\
\hline Canada & 7.77 & 3.15 & 5.826 \\
\hline Cyprus & 7.77 & 15.816 & 1.889 \\
\hline Belarus & 7.55 & 4.536 & 2.839 \\
\hline Slovenia & 7.38 & 2.973 & 3.3 \\
\hline Latvia & 7.26 & 10.364 & 7.847 \\
\hline Croatia & 7.24 & 3.776 & 4.191 \\
\hline Greece & 7.23 & 2.879 & 3.275 \\
\hline Lithuania & 7.19 & 4.504 & 4.832 \\
\hline $\begin{array}{c}\text { Czech } \\
\text { Republic }\end{array}$ & 7.16 & 13.443 & 13.195 \\
\hline Uruguay & 7.16 & 2.481 & 5.695 \\
\hline Portugal & 7.13 & 3.767 & 4.647 \\
\hline $\begin{array}{c}\text { Russian } \\
\text { Federation }\end{array}$ & 7.07 & 1.629 & 6.705 \\
\hline $\begin{array}{c}\text { Slovak } \\
\text { Republic }\end{array}$ & 7.06 & 16.176 & 13.396 \\
\hline Italy & 7.04 & 3.05 & 3.935 \\
\hline Hungary & 6.93 & 10.529 & 10.486 \\
\hline Poland & 6.89 & 7.729 & 7.742 \\
\hline Bulgaria & 6.86 & 5.065 & 4.193 \\
\hline
\end{tabular}

\begin{tabular}{|c|c|c|c|}
\hline Argentina & 6.79 & 2.75 & 6.256 \\
\hline Kazakhstan & 6.79 & 0.324 & 4.395 \\
\hline $\begin{array}{c}\text { Brunei } \\
\text { Darussalam }\end{array}$ & 6.75 & 0.165 & 2.337 \\
\hline Serbia & 6.61 & 5.491 & 2.851 \\
\hline Chile & 6.57 & 0.761 & 7.025 \\
\hline Romania & 6.48 & 7.262 & 6.016 \\
\hline Malaysia & 6.38 & 27.084 & 19.913 \\
\hline China & 5.60 & 25.805 & 17.872 \\
\hline $\begin{array}{c}\text { Total for } \\
\text { selected } \\
\text { countries }\end{array}$ & 358.02 & 380.251 & 312.750 \\
\hline $\begin{array}{c}\text { Average for } \\
\text { selected } \\
\text { countries }\end{array}$ & 7.62 & 8.090 & 6.654 \\
\hline
\end{tabular}

Source: Measuring the Information Society Report 2017; Official website of the World Bank

The data in Table 3 makes it possible to conclude that the level of participation of Russia in foreign economic activity is at a very low level, relative to the represented countries.

The assessment of the degree of integration of the Russian economy into the global economy was carried out on the basis of the formula of arithmetic weighted average.

The Index of the degree of integration of the national economy (Ij) is based on a number of private Indexes (formula 1).

$$
I_{j}=\frac{\sum_{i=1}^{n} a_{i} x_{i j}}{\sum_{i=1}^{n} a_{i}}
$$

$\mathrm{Ij}$ - the index of the degree of integration of the $\mathrm{j}$ country into the global economy;

$a_{i}$ - the weight value of the i Index;

$\mathrm{x}_{\mathrm{ij}}$ is the point score of the $\mathrm{i}$ Index for the $\mathrm{j}$ country; $\mathrm{I}=1,2, \ldots, \mathrm{n}$ is the number of Indexes of foreign economic activity used in the assessment;

$\mathrm{J}=1,2, \ldots, \mathrm{m}$ is the number of countries participating in the evaluation.

For example, the valuation Indexes can be expressed as $\mathrm{X} 1, \mathrm{X} 2, \mathrm{X} 3, \ldots \mathrm{Xn}$.

The point evaluation of FTA Indexes and their weight values are determined either by expert or calculated methods. The weighting value varies between $[0 ; 1]$. Their sum within the individual Index group is equal to one. By default, according to Laplace's rule, the weighting value is $1 / n$. Next, the quantity is multiplied by the weight of the Index, which is the contribution of a single Index to the overall integration Index.

We will calculate the degree of integration of the Russian Federation in the global economy. Quantitative evaluation of Indexes is estimated on the basis of the number of countries: 1 - the worst, 47 - the best. The weighting value is the same for all Indexes and is 0.33 (Table 4 ). 
Table 4 Calculation of the level of integration of Russia into the world economy using the method of arithmetic weighted

\begin{tabular}{|c|c|c|c|}
\hline Index & $\begin{array}{c}\text { Weight, } \\
a_{i}\end{array}$ & Estimate, $x_{i j}$ & Value, $a_{i} x_{i j}$ \\
\hline$X 1$ & $1 / 3$ & 14 & $42 / 3$ \\
\hline$X 2$ & $1 / 3$ & 4 & $11 / 3$ \\
\hline$X 3$ & $1 / 3$ & 31 & $101 / 3$ \\
\hline \multicolumn{4}{|c|}{ Total } \\
\hline
\end{tabular}

Source: The authors

Potentially, the Index of the state of integration of the country into the world economy can reach the maximum value of 47 points, the degree of integration of Russia into the world economy is 16.33 points. Thus, the calculations show that Russia is not sufficiently integrated into the world economy, it is necessary to increase the efficiency of the ICT sector, which will have a positive impact on electronic business (Kostin, 2018).

Similarly to the result of calculations using the weighted average method, calculations can be performed using the scoring method using the best value. The three-point rating system is applied in the table 5: 3 points - high level of integration into the world economy of the country $(96-141 \mathrm{cl}$.); 2 points - average (50 - $95 \mathrm{cl}$.); 1 point - low (3-49 pp.).

Table 5 Calculation of the assessment of the level of integration of the country into the world economy using the methods of sum of seats and points

\begin{tabular}{|c|c|c|c|c|c|c|}
\hline Country & $\begin{array}{c}\text { Index of } \\
\text { developmen } \\
\text { tof ICT, ICT } \\
\text { Developme } \\
\text { nt Index, X1 }\end{array}$ & $\begin{array}{c}\text { Share of } \\
\text { goods and } \\
\text { services } \\
\text { ICT in total } \\
\text { exports, } \\
\text { X2, } \%\end{array}$ & $\begin{array}{c}\text { Share of } \\
\text { goods of } \\
\text { ICT in the } \\
\text { general } \\
\text { import, } \\
\text { X3, } \%\end{array}$ & $\begin{array}{c}\text { Sum } \\
\text { of } \\
\text { points }\end{array}$ & Rank & Point \\
\hline $\begin{array}{c}\text { Brunei } \\
\text { Darussala } \\
\text { m }\end{array}$ & 6 & 1 & 3 & 10 & 47 & 1 \\
\hline Kazakhstan & 7 & 2 & 17 & 26 & 46 & 1 \\
\hline Italy & 12 & 13 & 12 & 37 & 45 & 1 \\
\hline Greece & 19 & 11 & 8 & 38 & 44 & 1 \\
\hline Serbia & 5 & 26 & 7 & 38 & 43 & 1 \\
\hline Chile & 4 & 3 & 33 & 40 & 42 & 1 \\
\hline Slovenia & 22 & 12 & 9 & 43 & 41 & 1 \\
\hline Argentina & 8 & 9 & 28 & 45 & 40 & 1 \\
\hline Uruguay & 16 & 8 & 24 & 48 & 39 & 1 \\
\hline Bulgaria & 9 & 24 & 16 & 49 & 38 & 1 \\
\hline $\begin{array}{c}\text { Russian } \\
\text { Federation }\end{array}$ & 14 & 4 & 31 & 49 & 37 & 1 \\
\hline Belarus & 23 & 21 & 6 & 50 & 36 & 2 \\
\hline Portugal & 15 & 16 & 20 & 51 & 35 & 2 \\
\hline Croatia & 20 & 17 & 15 & 52 & 34 & 2 \\
\hline Luxembour & 40 & 15 & 1 & 56 & 33 & 2 \\
\hline g & 26 & 18 & 13 & 57 & 32 & 2 \\
\hline Spain & 26 & & & \\
\hline
\end{tabular}

\begin{tabular}{|c|c|c|c|c|c|c|}
\hline Lithuania & 18 & 20 & 22 & 60 & 31 & 2 \\
\hline Romania & 3 & 30 & 27 & 60 & 30 & 2 \\
\hline Norway & 41 & 7 & 14 & 62 & 29 & 2 \\
\hline $\begin{array}{c}\text { New } \\
\text { Zealand }\end{array}$ & 36 & 5 & 23 & 64 & 28 & 2 \\
\hline Canada & 25 & 14 & 26 & 65 & 27 & 2 \\
\hline Austria & 30 & 25 & 11 & 66 & 26 & 2 \\
\hline Cyprus & 24 & 40 & 2 & 66 & 25 & 2 \\
\hline Iceland & 47 & 10 & 10 & 67 & 24 & 2 \\
\hline Switzerland & 45 & 19 & 5 & 69 & 23 & 2 \\
\hline France & 34 & 22 & 19 & 75 & 22 & 2 \\
\hline Australia & 35 & 6 & 35 & 76 & 21 & 2 \\
\hline Ireland & 29 & 43 & 4 & 76 & 20 & 2 \\
\hline Poland & 10 & 31 & 36 & 77 & 19 & 2 \\
\hline Finland & 27 & 34 & 21 & 82 & 18 & 2 \\
\hline Denmark & 44 & 23 & 18 & 85 & 17 & 2 \\
\hline Hungary & 11 & 37 & 40 & 88 & 16 & 2 \\
\hline China & 1 & 46 & 46 & 93 & 15 & 2 \\
\hline Latvia & 21 & 36 & 37 & 94 & 14 & 2 \\
\hline $\begin{array}{c}\text { United } \\
\text { Kingdom }\end{array}$ & 43 & 27 & 25 & 95 & 13 & 2 \\
\hline Malaysia & 2 & 47 & 47 & 96 & 12 & 3 \\
\hline Germany & 37 & 28 & 32 & 97 & 11 & 3 \\
\hline $\begin{array}{c}\text { Slovak } \\
\text { Republic }\end{array}$ & 13 & 41 & 44 & 98 & 10 & 3 \\
\hline $\begin{array}{c}\text { Czech } \\
\text { Republic }\end{array}$ & 17 & 39 & 43 & 99 & 9 & 3 \\
\hline Estonia & 32 & 33 & 34 & 99 & 8 & 3 \\
\hline Israel & 28 & 45 & 29 & 102 & 7 & 3 \\
\hline Sweden & 38 & 35 & 30 & 103 & 6 & 3 \\
\hline Japan & 39 & 29 & 38 & 106 & 5 & 3 \\
\hline $\begin{array}{l}\text { United } \\
\text { States }\end{array}$ & 33 & 32 & 41 & 106 & 4 & 3 \\
\hline $\begin{array}{c}\text { Netherland } \\
\mathrm{s}\end{array}$ & 42 & 38 & 39 & 119 & 3 & 3 \\
\hline Singapore & 31 & 44 & 45 & 120 & 2 & 3 \\
\hline $\begin{array}{c}\text { Korea, } \\
\text { Rep. }\end{array}$ & 46 & 42 & 42 & 130 & 1 & 3 \\
\hline
\end{tabular}

Source: The authors

The method of the sum of seats and the method of ballroom assessment allow to determine the degree of integration of a country, based on the level of development of the economy of that country, to identify problems in the process of integration. However, the disadvantage of these methods is that the difference between each pair of neighboring countries in the ranking is always constant. Based on the data presented in Table 5, it is recorded that the Russian Federation is the leader of the group of countries with low level of integration through ICT; from the entry into the group of countries with medium level of integration it lacks 1 point. Moving up one position 
on at least one Index will provide the Russian Federation with entry into the group of countries with medium level of integration. Values of all considered Indexes by the method of multivariate average are given in Table 6 .

Table 6 Calculation of the level of integration of Russia into the world economy using the method of multidimensional

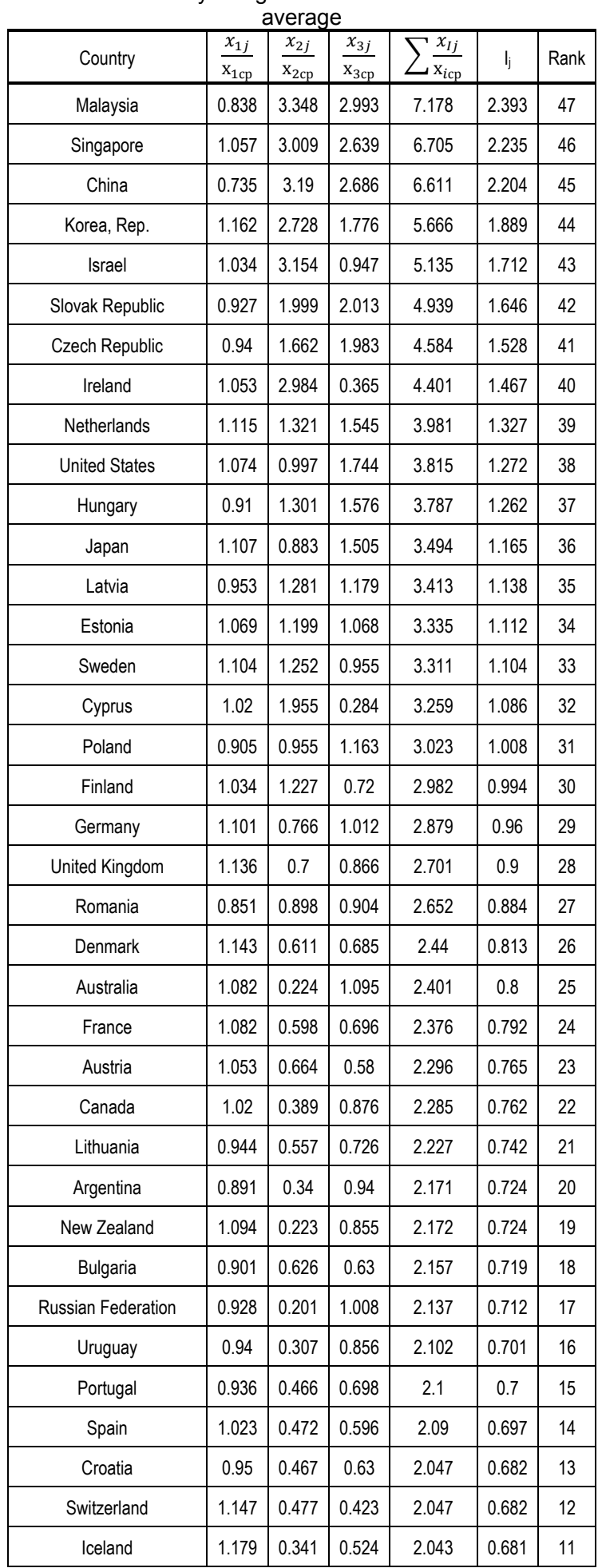

\begin{tabular}{|c|c|c|c|c|c|c|}
\hline Chile & 0.862 & 0.094 & 1.056 & 2.012 & 0.671 & 10 \\
\hline Norway & 1.112 & 0.293 & 0.606 & 2.011 & 0.67 & 9 \\
\hline Belarus & 0.991 & 0.561 & 0.427 & 1.978 & 0.659 & 8 \\
\hline Serbia & 0.868 & 0.679 & 0.428 & 1.975 & 0.658 & 7 \\
\hline Italy & 0.924 & 0.377 & 0.591 & 1.893 & 0.631 & 6 \\
\hline Slovenia & 0.969 & 0.367 & 0.496 & 1.832 & 0.611 & 5 \\
\hline Greece & 0.949 & 0.356 & 0.492 & 1.797 & 0.599 & 4 \\
\hline Luxembourg & 1.112 & 0.443 & 0.151 & 1.707 & 0.569 & 3 \\
\hline Kazakhstan & 0.891 & 0.04 & 0.66 & 1.592 & 0.531 & 2 \\
\hline Brunei Darussalam & 0.886 & 0.02 & 0.351 & 1.258 & 0.419 & 1 \\
\hline
\end{tabular}

Source: The authors

Table 6 shows that Malaysia (47 points) and Singapore (46 points) have the highest levels of integration. Russia ranks 31 st in terms of integration into the world economy among the selected countries.

The Pattern method uses the best values rather than the national averages (Table 7).

Table 7 Calculation of the level of integration of Russia into the world economy using the pattern method

\begin{tabular}{|c|c|c|c|c|c|c|}
\hline Country & $\frac{x_{1 j}}{x_{1 \max }}$ & $\frac{x_{2 j}}{\mathrm{x}_{2 \max }}$ & $\frac{x_{3 j}}{\mathrm{x}_{3 \max }}$ & $\sum \frac{x_{I j}}{\mathrm{x}_{\text {max }}}$ & $\mathrm{j}$ & Rank \\
\hline Malaysia & 0.71 & 1 & 1 & 2.71 & 0.903 & 47 \\
\hline Singapore & 0.896 & 0.899 & 0.882 & 2.677 & 0.892 & 46 \\
\hline China & 0.624 & 0.953 & 0.898 & 2.474 & 0.825 & 45 \\
\hline Korea, Rep. & 0.986 & 0.815 & 0.593 & 2.394 & 0.798 & 44 \\
\hline Israel & 0.878 & 0.942 & 0.316 & 2.136 & 0.712 & 43 \\
\hline $\begin{array}{c}\text { Slovak } \\
\text { Republic }\end{array}$ & 0.786 & 0.597 & 0.673 & 2.056 & 0.685 & 42 \\
\hline $\begin{array}{c}\text { Czech } \\
\text { Republic }\end{array}$ & 0.797 & 0.496 & 0.663 & 1.956 & 0.652 & 41 \\
\hline Ireland & 0.893 & 0.891 & 0.122 & 1.906 & 0.635 & 40 \\
\hline Netherlands & 0.945 & 0.395 & 0.516 & 1.856 & 0.619 & 39 \\
\hline $\begin{array}{c}\text { United } \\
\text { States }\end{array}$ & 0.911 & 0.298 & 0.583 & 1.792 & 0.597 & 38 \\
\hline Japan & 0.939 & 0.264 & 0.503 & 1.705 & 0.568 & 37 \\
\hline Hungary & 0.772 & 0.389 & 0.527 & 1.687 & 0.562 & 36 \\
\hline Sweden & 0.937 & 0.374 & 0.319 & 1.63 & 0.543 & 35 \\
\hline Estonia & 0.906 & 0.358 & 0.357 & 1.621 & 0.54 & 34 \\
\hline Latvia & 0.808 & 0.383 & 0.394 & 1.585 & 0.528 & 33 \\
\hline Cyprus & 0.865 & 0.584 & 0.095 & 1.544 & 0.515 & 32 \\
\hline Germany & 0.934 & 0.229 & 0.338 & 1.501 & 0.5 & 31 \\
\hline Finland & 0.878 & 0.367 & 0.241 & 1.485 & 0.495 & 30 \\
\hline $\begin{array}{c}\text { United } \\
\text { Kingdom }\end{array}$ & 0.963 & 0.209 & 0.289 & 1.462 & 0.487 & 29 \\
\hline Poland & 0.767 & 0.285 & 0.389 & 1.441 & 0.48 & 28 \\
\hline Denmark & 0.97 & 0.183 & 0.229 & 1.382 & 0.461 & 27 \\
\hline Australia & 0.918 & 0.067 & 0.366 & 1.351 & 0.45 & 26 \\
\hline France & 0.918 & 0.179 & 0.233 & 1.329 & 0.443 & 25 \\
\hline Romania & 0.722 & 0.268 & 0.302 & 1.292 & 0.431 & 24 \\
\hline & & & & & \\
\hline
\end{tabular}




\begin{tabular}{|c|c|c|c|c|c|c|}
\hline Austria & 0.893 & 0.198 & 0.194 & 1.285 & 0.428 & 23 \\
\hline $\begin{array}{c}\text { New } \\
\text { Zealand }\end{array}$ & 0.928 & 0.067 & 0.286 & 1.28 & 0.427 & 22 \\
\hline Iceland & 1 & 0.102 & 0.175 & 1.277 & 0.426 & 21 \\
\hline Canada & 0.865 & 0.116 & 0.293 & 1.274 & 0.425 & 20 \\
\hline Switzerland & 0.973 & 0.142 & 0.141 & 1.257 & 0.419 & 19 \\
\hline Norway & 0.943 & 0.087 & 0.202 & 1.233 & 0.411 & 18 \\
\hline Lithuania & 0.801 & 0.166 & 0.243 & 1.21 & 0.403 & 17 \\
\hline Spain & 0.867 & 0.141 & 0.199 & 1.207 & 0.402 & 16 \\
\hline $\begin{array}{c}\text { Russian } \\
\text { Federation }\end{array}$ & 0.787 & 0.06 & 0.337 & 1.184 & 0.395 & 15 \\
\hline Uruguay & 0.797 & 0.092 & 0.286 & 1.175 & 0.392 & 14 \\
\hline Argentina & 0.756 & 0.102 & 0.314 & 1.172 & 0.391 & 13 \\
\hline Portugal & 0.794 & 0.139 & 0.233 & 1.166 & 0.389 & 12 \\
\hline Bulgaria & 0.764 & 0.187 & 0.211 & 1.161 & 0.387 & 11 \\
\hline Croatia & 0.806 & 0.139 & 0.21 & 1.156 & 0.385 & 10 \\
\hline Belarus & 0.841 & 0.167 & 0.143 & 1.151 & 0.384 & 9 \\
\hline Luxembourg & 0.943 & 0.132 & 0.051 & 1.126 & 0.375 & 8 \\
\hline Chile & 0.732 & 0.028 & 0.353 & 1.113 & 0.371 & 7 \\
\hline Slovenia & 0.822 & 0.11 & 0.166 & 1.097 & 0.366 & 6 \\
\hline Italy & 0.784 & 0.113 & 0.198 & 1.094 & 0.365 & 5 \\
\hline Serbia & 0.736 & 0.203 & 0.143 & 1.082 & 0.361 & 4 \\
\hline Greece & 0.805 & 0.106 & 0.164 & 1.076 & 0.359 & 3 \\
\hline Kazakhstan & 0.756 & 0.012 & 0.221 & 0.989 & 0.33 & 2 \\
\hline $\begin{array}{c}\text { Brunei } \\
\text { Darussalam }\end{array}$ & 0.752 & 0.006 & 0.117 & 0.875 & 0.292 & 1 \\
\hline & & & & & 1 \\
\hline
\end{tabular}

Source: The authors

The leaders in Table 7 are Malaysia (47 points) and Singapore (46 points). Russia also ranks $33^{\text {rd }}$ among selected countries when assessed using other methods. According to the pattern method, the level of integration of Russia is slightly lower than in calculations using the multidimensional average method. This is due to the fact that in the latter case it uses not the average level, but the maximum Index among the countries selected for analysis, and the dynamics of imports of goods and services related to ICT in Russia is higher (the Index is $6.7 \%$ of the total volume of imports of goods and services).

Table 8 provides a summary table of Russia's integration level by selected methods.

Table 8 Summary table of assessment of the level of integration of Russia into the world economy

\begin{tabular}{|l|l|l|l|l|}
\hline Method & Index & $\begin{array}{l}\text { Minimum } \\
\text { Index }\end{array}$ & $\begin{array}{l}\text { Maximum } \\
\text { Index }\end{array}$ & Average \\
\hline $\begin{array}{l}\text { Method of the arithmetic } \\
\text { average }\end{array}$ & 16,33 & 1 & 47 & 23,5 \\
\hline $\begin{array}{l}\text { Method of sum of points } \\
\text { and scores }\end{array}$ & 1 & 1 & 3 & 2 \\
\hline $\begin{array}{l}\text { Method of } \\
\text { multidimensional } \\
\text { average }\end{array}$ & 0,712 & 0,419 & 2,393 & 1 \\
\hline Method of patterns & 0,395 & 0,292 & 0,903 & 0,494 \\
\hline
\end{tabular}

Source: The authors
Thus, it can be noted that Russia's level of integration is not high enough. This determines the relevance of developing measures to increase Russia's integration (and competitiveness as well, according to Miller \& Miller, 2019) into the world economy.

\section{Improving the efficiency of e- business as a way to integrate Russia into the world economy}

Taking into account the identified trends and factors of integration of the Russian Federation into the modern international financial and economic environment, we shall propose a means to optimize electronic business through a progressive tool - neural network technologies. An example of an implementation algorithm is proposed for the service sector, namely enterprises engaged in activities on implementation of services in an electronic environment, however, it can be implemented in the trade sphere (for example, retail trade).

The service sector is one of the most promising and rapidly developing industries in most economies at the present stage of development of the world community. It is under the influence of various factors, including rapid change of economic conditions, improvement of quality of provided services, constant replenishment of the market by new participants, including foreign competitors. These changes have a significant impact on the efficiency of the work of, among other things, Russian enterprises representing the service sector. At present, the tools and technologies of only the traditional management apparatus can no longer ensure the successful functioning of companies representing this sphere (Kostin, 2016).

The intensity of the use of modern information and communication technologies is one of the priority conditions for the sustainable formation of competitive advantages (Kostin \& Berezovskaya, 2017). Increasing competitiveness in almost any industry, including services, is possible through the use of automated management systems and systems related to data storage and intelligent processing. Neural networks are now widespread (Kostin \& Berezovskaya, 2019).

Using the example of implementation of revenue-management at enterprises operating in the electronic environment, the algorithm of implementation of neural network technology is proposed (Picture 2).

Revenue-management is a set of measures 
carried out daily to manage inventory and effective sale of goods/services. Based on the obtained data, reports are prepared, which provide an opportunity to obtain a complete picture of the current state of the market, the position of competitors, hence allowing to adjust the sales strategy. In other words, revenue management is a pricing policy based on the analysis of consumer demand in a certain period of time. It is aimed at ensuring high profitability of the enterprise.

Let us take a closer look at the stages of demand detection. The algorithm allows to obtain data on consumers: on the basis of surveys and tests in social networks the level of consumer interest in various services of the enterprise is analyzed. Structuring takes place according to the services offered by the enterprise and according to personal data (age, sex, nationality, place of residence, education and contact information - data that could be obtained from the profiles of respondents). Based on the data obtained, the number of respondents of a certain category who prefer a particular service of the enterprise is calculated. Accordingly, a certain service of the enterprise is offered to its category of consumers, more of whom chose this service in surveys and tests.

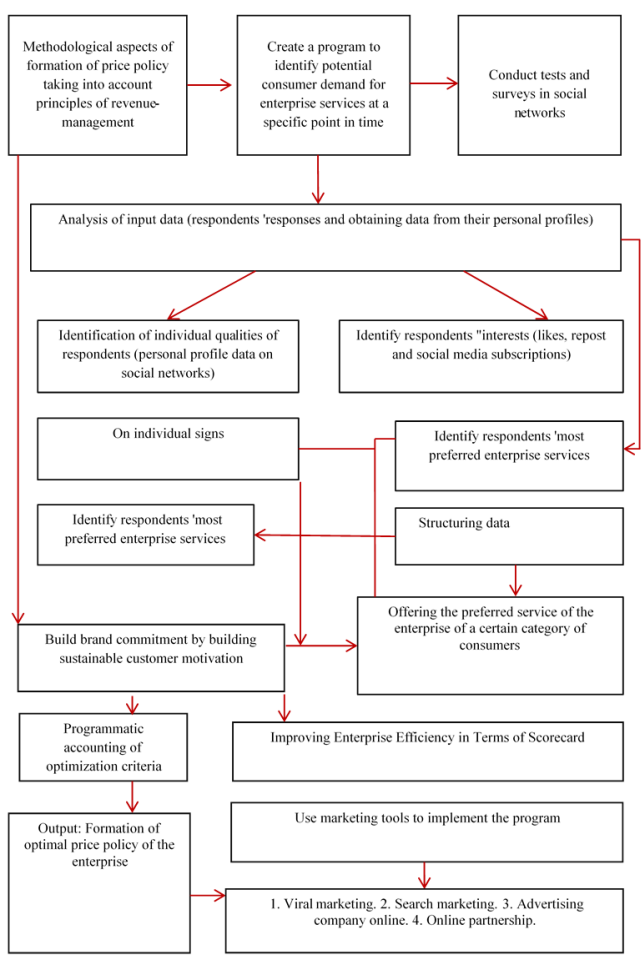

Figure 2 Algorithm of consumer demand estimation based on application of neural network technologies Source: The authors

Based on the data obtained in the program, it is possible to form a proposal that is individual for each customer or potential consumer. Two options for using the obtained data will be used: 1) development of a site - a landing page for each consumer; 2) advertising of goods/services of the company in public Internet access. Consider both options:

1) The term "lending-page" is formed from the English phrase of "landing page", in translation meaning just the landing, landing (grounding) page. Lendings are created taking into account the psychology of visitors. They must cling and not release them until the very moment of purchase (or registration).

Depending on the goals pursued, it is possible to divide landing pages (lendings) into several types (Figure 3).

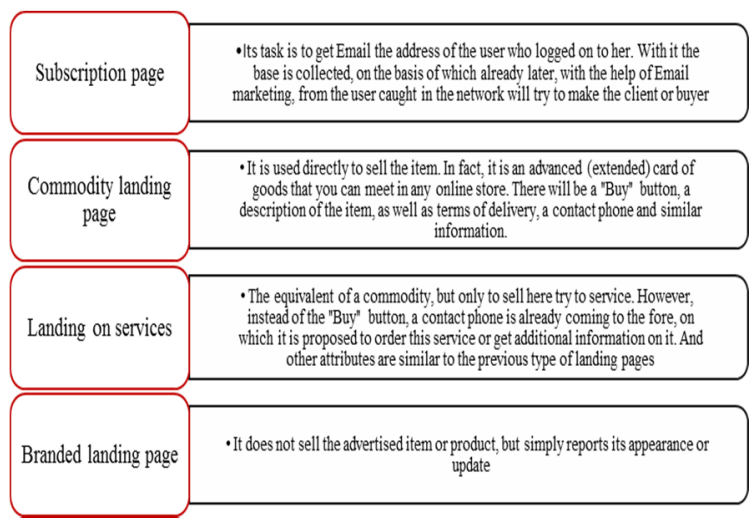

Figure 3 Types of lending pages Source: The authors

On the basis of structured groups of users, the program will allow to create a lending page, fully adapted to interests at a certain point in time of the potential client individually. The number of pages usually reaches 6-8 pieces, that is, structuring customers will include 6-8 categories of consumers.

2) As in the previous version, the algorithm on which the activity is based can offer the consumer a certain product/service, but not on the page of the company specially created, but through advertising.

The proposed algorithm was tested in 5 Russian companies that are representatives of electronic business. These include: LLC "Infinity Concert," LLC "Eclectica," LLC "M-Advertising" LLC "MGroup," IE "Balchugov." On the basis of the introduction of efficiency technology we have previously proposed, relevant data have been obtained showing the improvement of efficiency of companies. For calculations, relevant data was used for those areas of activity that could be 
attributed to the electronic sphere. Data cannot be characterized as aggregate.

Table 9 Evaluation of efficiency of implementation of the proposed revenue-management algorithm with elements of lending promotion in domestic companies, 2016 (before implementation); 2017. (After implementation)

\begin{tabular}{|c|c|c|c|c|c|c|c|c|c|c|}
\hline \multirow{3}{*}{ Index } & \multicolumn{10}{|c|}{ Companies } \\
\hline & \multicolumn{5}{|c|}{ Before } & \multicolumn{5}{|c|}{ Later } \\
\hline & 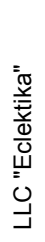 & 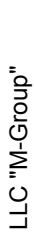 & 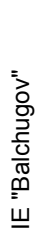 & 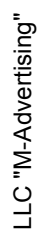 & 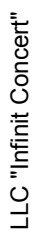 & 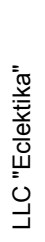 & 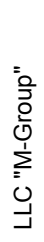 & 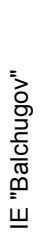 & 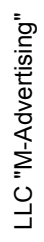 & 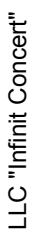 \\
\hline $\begin{array}{l}\text { Return } \\
\text { on } \\
\text { assets } \\
\%\end{array}$ & $\begin{array}{l}\bar{\infty} \\
\dot{f}\end{array}$ & $\begin{array}{l}\infty \\
0 \\
0\end{array}$ & $\frac{E}{60}$ & $\begin{array}{l}\text { : } \\
\text { Li } \\
\leftarrow\end{array}$ & $\begin{array}{l}\infty \\
\stackrel{-}{0} \\
0 \\
\end{array}$ & $\begin{array}{l}\hat{\sigma} \\
\dot{\sigma}\end{array}$ & $\begin{array}{l}\text { ब } \\
6\end{array}$ & $\begin{array}{l}\hat{6} \\
\infty\end{array}$ & $\begin{array}{l}\text { o } \\
\stackrel{9}{0} \\
0\end{array}$ & $\begin{array}{l}\hat{\infty} \\
\text { mo } \\
\text { ma }\end{array}$ \\
\hline $\begin{array}{l}\text { Return } \\
\text { on } \\
\text { sales } \\
\%\end{array}$ & 今 & $\begin{array}{l}\widehat{\infty} \\
\infty \\
\end{array}$ & 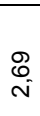 & $\begin{array}{l}\stackrel{\infty}{\Omega} \\
\stackrel{N}{\sim}\end{array}$ & $\begin{array}{l}\infty \\
0 \\
0\end{array}$ & $\underset{6}{\stackrel{9}{+}}$ & $\begin{array}{l}\infty \\
0 \\
10\end{array}$ & 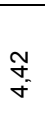 & $\begin{array}{l}\stackrel{L}{0} \\
\stackrel{5}{5}\end{array}$ & $\begin{array}{l}\stackrel{2}{N} \\
F\end{array}$ \\
\hline $\begin{array}{l}\text { Abso- } \\
\text { lute } \\
\text { liqu- } \\
\text { idity,\% }\end{array}$ & $\begin{array}{l}\stackrel{R}{0} \\
0\end{array}$ & $\stackrel{0}{0}$ & $\begin{array}{l}\mathscr{8} \\
0\end{array}$ & $\stackrel{\hat{m}}{\mathrm{~N}}$ & $\begin{array}{l}\text { N } \\
\text { N }\end{array}$ & $\begin{array}{l}R \\
0 \\
0\end{array}$ & $\begin{array}{l}N \\
0 \\
0\end{array}$ & $\begin{array}{l}\widetilde{N} \\
0 \\
0\end{array}$ & $\stackrel{m}{\circ}$ & $\stackrel{\circ}{\sigma}$ \\
\hline
\end{tabular}

Source: The authors

Based on the obtained results (Table 9), it can be noted that efficiency after implementation increases (for example, return on sales increased in all 5 enterprises on average by $54.36 \%$ ). However, we believe that the assessment is not enough complete. Given that modern performance measurement methods do not cover specific ebusiness performance indicators such as conversion, customer value, time spent using the eplatform, on which the company operates, and a number of others. Hence the e-business performance evaluation method has been developed.

\section{E-business performance assessment method as part of the assessment of the country's integration into the world economy}

The need for objective analysis of the efficiency of the e-business enterprise is due not only to the degree of perspective of investments in the transformation of its activities from the traditional sector (see for example: Grubor, A., Milovanov O.; Nica, E., 2018) to the digital sector, but also to the dynamism of economic development itself in the neuro-network era (see for example: Sudarević T., Marić D., 2018; Popescu, G. H., 2018). Electronic principles of operation of the e-business enterprise differ from traditional ones and dictate the need to develop methods of evaluation of indicators characterizing its financial condition, level of investment attractiveness and competitiveness taking into account the specifics of operation of electronic platforms. The developed system of indicators in the future can serve as a basis for the formation of a strategy for assessing the efficiency of the e-business enterprise on the basis of the proposed algorithm for assessing the efficiency of e-business (Index AAB, where A - attractive, A artistic, $\mathrm{B}$ - business (hereinafter - AAB index).

The following groups of indicators will be included in the indicator framework of the $\mathrm{AAB}$ index:

1. Indicators of investment attractiveness assessment;

2. Indicators of assessment of financial stability of the enterprise;

3. Specialized indicators of evaluation of ebusiness development;

4. Indicators of competitiveness and integration.

The methodology we propose is shown in Figure 4.
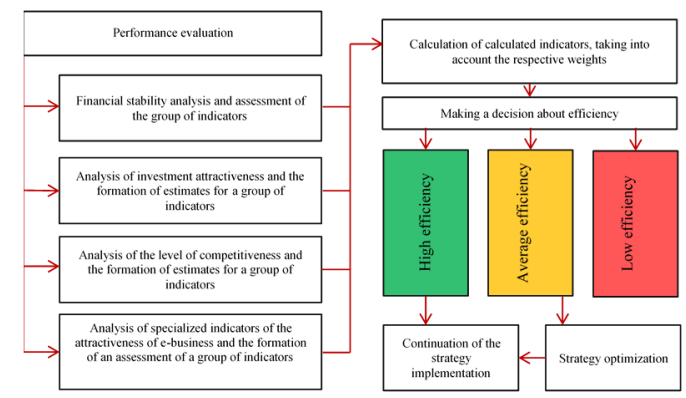

Figure 4 The stages of determining the effectiveness of ebusiness

Source: The authors based on Kostin, 2015

We have developed the program "AAB", which allows to automate the conduct of the calculation of the effectiveness of electronic business (program code written in the programming language Golang). Excerpt from program code: «Package main import (

"aab/handlers"

"fmt"

"strconv"

"time"

)

func main() \{

handlers.Init()

currentYear, err := strconv.Atoi(time.Now().Format("2006"))

startYear := currentYear - handlers.Period

if err != nil \{

fmt.Println(err.Error())

\}

for year := startYear; year < currentYear; year++ \{

fmt.Println("Заполняем данные для " + strconv.ltoa(year) + 
" года.")

handlers.InsertedData[year] handlers.ParseDataForYear(handlers.InsertedData[year])

handlers.CalcData()

handlers.ShowDataTable()

handlers.ShowGrowthRateTable()

handlers.ShowGradeTable()

handlers. CalcAAB ()

\}»

Based on the analysis, it can be noted that with the help of the AAB index, it becomes possible to determine the company's position on the international market for goods and services sold in the electronic environment, identify its level of financial sustainability and investment attractiveness, as well as assess the level of effectiveness of the e-business strategy. Considering that the "AAB Index" allows to evaluate the above-mentioned categories, it becomes an optimal tool for use in international companies operating in the market of goods and services sold in the electronic environment.

\section{Development of the country's integration into the world economy}

Taking into account that the level of integration of the country depends on the efficiency of the companies of that country, it is proposed to supplement the methodology of assessing the level of integration of the country into the world economy with an indicator of the efficiency of companies that are representatives of e-business. The updated algorithm for assessing the country's integration into the world economy is shown in Figure 5.

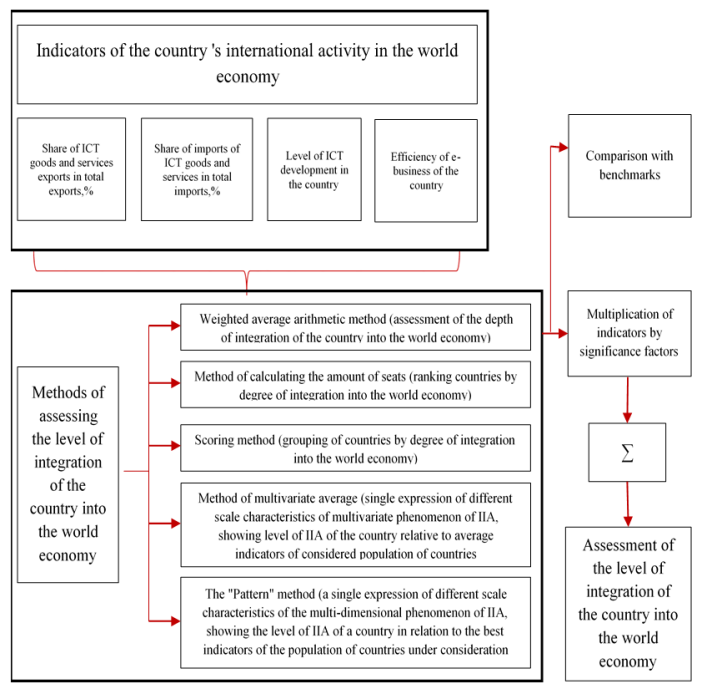

Figure 5 Algorithm for assessing the integration of the country into the world economy

Source: compiled by the authors on the basis of the data of Figure 1

We will assess the level of integration of Russia into the world economy on the basis of comparison of the indicators of 2016 and 2017 - the period before and after the introduction of the neural network technology offered by us to increase the efficiency of electronic business. In the calculations, the company indicator will be averaged (based on the calculation of 5 companies (data on the application fully automated and translated into the electronic environment) using the automated program "AAB") in order to assess the national average level of e-business efficiency and the overall level of integration taking into account the efficiency of e-business as its factor.

Table 10 Data for calculation of indcators of integration of the Russian Federation into the world economy, 2016-2017

\begin{tabular}{|c|c|c|c|}
\hline \multirow[t]{2}{*}{ Input data } & \multirow[t]{15}{*}{ Calculation } & \multicolumn{2}{|c|}{ Year/Result } \\
\hline & & 2016 & 2017 \\
\hline $\begin{array}{lr}\text { ICT Development } & \text { Index } \\
\text { (Measuring } & \text { the } \\
\text { Information } & \text { Society } \\
\text { Report 2017) } & \end{array}$ & & 6,9 & 7,07 \\
\hline $\begin{array}{l}\text { Exports of goods and } \\
\text { services (BoP, current } \\
\text { US\$) (Exports of goods } \\
\text { and services) }\end{array}$ & & $\begin{array}{l}33235261 \\
0000,0\end{array}$ & $\begin{array}{l}411178710 \\
000,0\end{array}$ \\
\hline $\begin{array}{l}\text { Imports of goods and } \\
\text { services (BoP, current } \\
\text { US\$) (Imports of goods } \\
\text { and services) }\end{array}$ & & $\begin{array}{l}26609656 \\
0000,0\end{array}$ & $\begin{array}{l}326989600 \\
000,0\end{array}$ \\
\hline $\begin{array}{llr}\text { Goods } & \text { exports } & \text { (BoP, } \\
\text { current } & \text { US\$) } & \text { (Goods } \\
\text { exports) } & & \\
\end{array}$ & & $\begin{array}{l}28170901 \\
0000,0\end{array}$ & $\begin{array}{l}353547360 \\
000,0\end{array}$ \\
\hline $\begin{array}{llr}\begin{array}{l}\text { Goods } \\
\text { current }\end{array} & \text { US } \$ \text { ) } & \text { (BoP, } \\
\text { (Goods } \\
\text { imports) }\end{array}$ & & $\begin{array}{l}19149432 \\
0000,0\end{array}$ & $\begin{array}{l}238125430 \\
000,0\end{array}$ \\
\hline $\begin{array}{l}\text { ICT service exports (BoP, } \\
\text { current US\$) (ICT service } \\
\text { exports) }\end{array}$ & & $\begin{array}{l}39037200 \\
00,0\end{array}$ & $\begin{array}{l}465275000 \\
0,0\end{array}$ \\
\hline $\begin{array}{l}\text { Communications, } \\
\text { computer, etc. ( } \% \text { of } \\
\text { service exports, BoP) } \\
\text { (Communications, } \\
\text { computer, etc. (a) }\end{array}$ & & 47,8 & 47,7 \\
\hline $\begin{array}{l}\text { Communications, } \\
\text { computer, etc. ( } \% \text { of } \\
\text { service imports, BoP) } \\
\text { (Communications, } \\
\text { computer, etc. (u) }\end{array}$ & & 48,0 & 44,9 \\
\hline $\begin{array}{l}\text { ICT service exports (\% of } \\
\text { service exports, BoP) (ICT } \\
\text { service exports) }\end{array}$ & & 7,7 & 8,1 \\
\hline $\begin{array}{l}\text { ICT goods exports (\% of } \\
\text { total goods exports (ICT } \\
\text { goods exports) }\end{array}$ & & 0,5 & 0,6 \\
\hline $\begin{array}{l}\text { ICT goods imports (\% total } \\
\text { goods imports) (ICT goods } \\
\text { imports) }\end{array}$ & & 8,9 & 9,2 \\
\hline $\begin{array}{llr}\text { Service } & \text { exports } & \text { (BoP, } \\
\text { current } & \text { US\$) } & \text { (Service } \\
\text { exports) } & & \\
\end{array}$ & & $\begin{array}{l}50643600 \\
000,0\end{array}$ & $\begin{array}{l}998239704, \\
1\end{array}$ \\
\hline $\begin{array}{llr}\text { Service } & \text { imports } & \text { (BoP, } \\
\text { current } & \text { US\$) } & \text { (Service } \\
\text { imports) } & & \\
\end{array}$ & & $\begin{array}{l}74602240 \\
000,0\end{array}$ & $\begin{array}{l}102801803 \\
7,9\end{array}$ \\
\hline $\begin{array}{l}\text { Export of goods ICT, } \\
\text { ICT,US dollar }\end{array}$ & $\begin{array}{ll}\text { ICT } & \text { goods } \\
\text { exports / Goods } \\
\text { exports * } 100 \%\end{array}$ & $\begin{array}{l}15409482 \\
84,7\end{array}$ & $\begin{array}{l}204464664 \\
2,4\end{array}$ \\
\hline ICT, US dollar & $\begin{array}{ll}\text { ICT } & \text { goods } \\
\text { imports } / \text { Goods } \\
\text { imports } * 100 \%\end{array}$ & $\begin{array}{l}16958736 \\
979,2\end{array}$ & $\begin{array}{l}219249295 \\
45,4\end{array}$ \\
\hline $\begin{array}{l}\text { Share of ICT goods and } \\
\text { services in total exports, } \%\end{array}$ & $\begin{array}{l}\text { ICT service } \\
\text { exports + Export }\end{array}$ & 1,638 & 1,629 \\
\hline
\end{tabular}




\begin{tabular}{|l|l|l|l|}
\hline & $\begin{array}{l}\text { of goods of ICT) } \\
\text { I Exports of } \\
\text { goods and } \\
\text { services * 100\% }\end{array}$ & & \\
\hline $\begin{array}{l}\text { Share of ICT goods in total } \\
\text { imports,\% }\end{array}$ & $\begin{array}{l}\text { Imports of ICT } \\
\text { goods, US \$ }\end{array}$ & 6,373 & 6,705 \\
$\begin{array}{l}\text { USA / Imports of } \\
\text { goods and } \\
\text { services (BoP, } \\
\text { current US\$) * } \\
100 \% \text {. }\end{array}$ & & \\
\hline
\end{tabular}

Source: The authors

Based on the calculations made (Table 10), the data needed for calculating the indicators of integration of the Russian Federation into the world economy were obtained (Table 11).

Table 11 Data for calculation of the level of integration of the Russian Federation into the world economy, 2016-2017

\begin{tabular}{|c|c|c|c|c|}
\hline \multirow[t]{2}{*}{ Year } & Indicator & & & \\
\hline & $\begin{array}{l}\text { Level of ICT } \\
\text { development } \\
\text { in the country } \\
\text { (ICT } \\
\text { Development } \\
\text { Index) }\end{array}$ & $\begin{array}{l}\text { Share of } \\
\text { ICT } \\
\text { exports of } \\
\text { goods and } \\
\text { services in } \\
\text { total } \\
\text { exports of } \\
\text { goods and } \\
\text { services, \% } \\
\text { (x2) }\end{array}$ & $\begin{array}{l}\text { Share of ICT } \\
\text { goods and } \\
\text { services } \\
\text { imports in } \\
\text { total exports } \\
\text { of goods } \\
\text { and } \\
\text { services, \% } \\
\text { (x3) }\end{array}$ & $\begin{array}{l}\text { Level of efficiency } \\
\text { of e-business } \\
\text { (average for } 5 \\
\text { companies } \\
\text { before and after } \\
\text { implementation } \\
\text { of our proposed } \\
\text { algorithm) (x4) }\end{array}$ \\
\hline 2016 & 6,91 & 1,638 & 6,373 & 0,065 \\
\hline 2017 & 7,07 & 1,629 & 6.705 & 0,135 \\
\hline
\end{tabular}

The maximum weight factor $(40 \%)$ is the "level of efficiency of electronic business," considering that the efficiency of integration of the country into the world economy depends on the efficiency of companies operating in the world market of goods and services, in particular, electronic. The weight of the other three indicators is $20 \%$.

The data is compared with the reference values (table 12) and based on the results of the comparison, the integration is evaluated using the selected methods. The benchmarks of the level of ICT development in the country, the share of exports and imports of ICT goods and services in the total volume of exports and imports of goods and services in this table are the average indicator of the maximum, average and minimum value for 200 countries of the world in 2017. The value of the indicator varies between $[-1 ; 1]$.

Table 12 Reference values of indicators of integration of the country into the world economy

\begin{tabular}{|c|c|c|c|}
\hline \multirow[t]{2}{*}{ Index } & \multicolumn{3}{|l|}{ Reference Value } \\
\hline & 3 & 2 & 1 \\
\hline 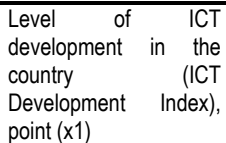 & $8,98=>x>5,123$ & $=5,123$ & $\begin{array}{l}0,96>=x<5,1 \\
23\end{array}$ \\
\hline $\begin{array}{l}\text { Share of ICT services } \\
\text { exports in total exports } \\
\text { of goods and } \\
\text { services, } \%(x 2)\end{array}$ & $43,31=>x>4,194$ & $=4,194$ & $0>=x<4,194$ \\
\hline
\end{tabular}

\begin{tabular}{|l|l|l|l|}
\hline $\begin{array}{l}\text { Share of ICT-related } \\
\text { imports in total exports } \\
\text { of goods and } \\
\text { services, } \%(x 3)\end{array}$ & $45,575=>x>3,81$ & $=3,81$ & $0>=x<3,81$ \\
\hline $\begin{array}{l}\text { E-Business Efficiency } \\
\text { Level }(x 4) \text { total }\end{array}$ & $1=>x>0$ & $=0$ & $0>=x<1$ \\
\hline Total & 12 & 8 & 4 \\
\hline
\end{tabular}

Table 13 provides an assessment of the degree of integration of the Russian economy into the global economy, which was carried out using the arithmetic weighted average formula. The results are ranked according to the indicator level relative to the reference value (where 1 is the lowest level, 2 is the middle level, 3 is the highest level). Thus, the value can vary from 4 to 12 . And taking into account the significance factor - from 1 to 3 .

Table 13 Calculation of the level of integration of Russia into the world economy by comparing data with the benchmark

\begin{tabular}{|c|c|c|c|c|c|}
\hline Index & $\begin{array}{l}\text { Weigh } \\
t, a_{i}\end{array}$ & $\begin{array}{l}\text { Assessme } \\
\mathrm{nt} \quad(2016) \text {, } \\
\mathrm{x}_{\mathrm{ij}}\end{array}$ & $\begin{array}{l}\text { Assessme } \\
\text { nt }(2017) \text {, } \\
x_{i j}\end{array}$ & $\begin{array}{l}\text { Indicatio } \\
n \\
(2016), \\
a_{i} x_{i j}\end{array}$ & $\begin{array}{l}\text { Indicatio } \\
n \\
(2017), \\
a_{i} x_{i j}\end{array}$ \\
\hline $\begin{array}{l}\text { X1 (ICT } \\
\text { Developme } \\
\text { nt Index- } \\
2017 \text { ) }\end{array}$ & 0,20 & 6,91 & 7,07 & 0,6 & $0,6 \uparrow$ \\
\hline $\mathrm{X} 2$ & 0,20 & 1,638 & 1,629 & 0,2 & $0,2 \downarrow$ \\
\hline $\mathrm{X3}$ & 0,20 & 6,373 & 6,075 & 0,6 & $0,6 \uparrow$ \\
\hline $\mathrm{X} 4$ & 0,40 & 0,065 & 0,135 & 1,2 & $1,2 \uparrow$ \\
\hline \multicolumn{4}{|l|}{ Total } & 2,6 & $2,6 \uparrow$ \\
\hline
\end{tabular}

where the arrow shows the change of the indicator relative to the previous period.

With regard to the level of integration of the Russian Federation into the world economy, obtained by the method proposed, it can be noted that the level of integration equals 2.6 points, which is 0.4 points lower than the highest reference value. The level in 2016 and 2017 is the same, but the dynamics of indicators ( 3 out of 4 ) is positive.

Based on the data received, it can be noted that in 2017 the level of integration of Russia into the world economy increased on average by $25 \%$ relative to the indicator of 2016. First of all, such increase could be explained via the increase in the efficiency of the representatives of electronic business. This confirms the attractiveness of the implementation of the proposed developments in this article to increase the efficiency of enterprises operating in the electronic environment and the methodology of assessing the efficiency of electronic business as an indicator of the overall integration of Russia into the world economy. 


\section{Conclusion}

The goal of the article was in the development of relevant methodology for assessing the integration of countries into the world economy. Theoretical and practical aspects of "neural network modelling" have been developed and the degree of its use in the process of increasing the efficiency of electronic business has been revealed. In particular, a number of conclusions and provisions have been formulated:

1. Processes of integration of enterprises and, as a result, countries into the world economy are possible due to optimization of their activities.

2. The ability to increase the efficiency of a certain enterprise becomes possible via the utilization of neural network technologies, one of which was proposed in this article. Its implementation can be supplemented by an efficiency assessment tool.

3. On the basis of modelling the methodology of assessing the efficiency of electronic business, proposing criteria and benchmarks of its activity, the tools for the development of the digital economy can be developed.

4. Another goal was also to develop a set of performance indicators for international companies operating in an electronic environment using information and communication technologies. The proposed complex is considered as a basis for the development of relevant method of assessing the effectiveness of e-business, which is one of the elements of the assessment of the indicator "the degree of integration of the country into the world economy." Among the main features and characteristics that distinguish it from existing methods of measuring the effectiveness of electronic business are the level of financial stability, competitiveness, investment attractiveness and indicators of specific activity of international companies in the electronic environment, which all have been accounted for.

5. The methodology of integration evaluation using the method of e-business efficiency assessment is developed. The method was tested via the developed for this purpose program code "AAB" (written in the programming language Golang) on the basis of the data of the analysis of the companies operating on the Russia market.sm

\section{References}

Communications, computer, etc. (2018a) (\% of service exports). The data of the World Bank. Retrieved from https://data.worldbank.org/Index/BX.GSR.CMCP.ZS?en $\mathrm{d}=2018$ \&locations $=$ RU\&start $=1994 \&$ view $=$ chart
Communications, computer, etc. (2018b) (\% of service imports). The data of the World Bank. Retrieved from https://data.worldbank.org/Index/BM.GSR.CMCP.ZS?e nd=2018\&locations=RU\&start=1994\&view=chart

Dynamics of exports and imports by country (2019). Official website of the World Bank. Retrieved from https://data.worldbank.org/Index

Exports of goods and services (2018). The data of the World Bank. Retrieved from https://data.worldbank.org/Index/BX.GSR.GNFS.CD?en $d=2016 \&$ start $=2016 \&$ view $=$ chart

Goods exports (2018). The data of the World Bank Retrieved from https://data.worldbank.org/lndex/BX.GSR.MRCH.CD?e nd $=2016 \&$ start $=2016 \&$ view $=$ chart

Goods imports (2018). The data of the World Bank. Retrieved from https://data.worldbank.org/Index/BM.GSR.MRCH.CD?e nd $=2016 \&$ start $=2016 \&$ view $=$ chart

Grubor, A.,\& Milovanov O.. (2017). Brand Strategies in the Era of Sustainability. Interdisciplinary Description of Complex Systems (15), 78-88. https://doi.org/10.7906/indecs.15.1.6

Goreckaya, E.O., \& Kosulina, T.A. (2011) Methods for assessing the degree of integration of the subjects of the southern Federal district of the Russian Federation in the world economy [Metody ocenki stepeni integracii sub"ektov YUzhnogo federal'nogo okruga rossijskoj Federacii v mirovuyu ekonomiku]. Regional Economics: theory and practice (In Russian). Retrieved September 13, 2019 from https://cyberleninka.ru/article/n/metodyotsenki-stepeni-integratsii-subektov-yuzhnogofederalnogo-okruga-rossiyskoy-federatsii-v-mirovuyuekonomiku-1

ICT Development Index-2017. Measuring the Information Society Report. (2017). ITU. Retrieved from https://www.itu.int/net4/ITU-D/idi/2017/index.html

ICT goods exports (2018). The data of the World Bank. Retrieved from https://data.worldbank.org/Index/TX.VAL.ICTG.ZS.UN? end $=2017$ \&locations $=$ RU\&start $=2000$ \& view $=$ chart

ICT goods imports (2018). The data of the World Bank. Retrieved from https://data.worldbank.org/Index/TM.VAL.ICTG.ZS.UN? end $=2017$ \&locations $=$ RU\&start $=2000$ \& view $=$ chart

ICT service exports (2018) The data of the World Bank Retrieved from https://data.worldbank.org/Index/BX.GSR.CCIS.CD?en $d=2018$ \&start $=1960$ \&view $=$ chart

Imports of goods and services (2018) The data or the World Bank. Retrieved from https://data.worldbank.org/Index/BM.GSR.GNFS.CD?e nd $=2016 \&$ start $=2016 \&$ view $=$ char

Hoffman M., \& Gurkov A. (2017) Europe of two speedsMerkel's attempt to save the EU [Evropa dvuh skorostej - popytka Merkel' spasti EC] (In Russian). Made for minds. Retrieved September 13, 2019 from https://www.dw.com/ru/европа-двух-скоростейпопытка-меркель-спасти-еc/a-37502062

Hyers, D., \& and Kovacova, M. (2018). The economics of the online gig economy: Algorithmic hiring practices, digital labor-market intermediation, and rights for platform workers. Psychosociological Issues in Human Resource Management, 6(1), 160-165. https://doi.org/10.22381/PIHRM6120187 
Kaveshnikov, N.YU. (2009) Lisbon Treaty: how the European Union is changing [Lissabonskij dogovor: kak menyaetsya Evropejskij soyuz] Outlook. (In Russian). Retrieved September 13, 2019 from http://www.perspektivy.info/print.php?ID=44723

Kostin K.B. \& Berezovskaya A.A. (2017). Current state and prospects of the global e-business development. [Sovremennoe sostoyanie i perspektivy razvitiya mirovogo elektronnogo biznesa]. Russian Journal of Entrepreneurship, 18(24). (in Russian). https://doi.org/10.18334/rp.18.24.38563

Kostin K.B., Berezovskaya A.A. (2019). Modern technologies of digital economy as a driver of growth of the world market of goods and services. [Sovremennye tekhnologii cifrovoj ekonomiki kak drajver rosta mirovogo rynka tovarov i uslug] Economic attitude. 9(2) in Russian),122-129.

Kostin, K. B. (2016) Methodology of development of marketing tools and evaluation of the effectiveness of entrepreneurship in tourism, [Metodologiya razvitiya instrumentariya marketinga i ocenki effektivnosti predprinimatel'stva v sfere turizma] (in Russian) Unpublished doctoral dissertation, SpB., 337.

Kostin, K.B. (2015) Classification and methodology for assessing the investment attractiveness of transnational corporations in international business. [Klassifikatsiya $i$ metodologiya otsenki investitsionnoy privlekatel'nosti transnatsional'nykh korporatsiy $v$ mezhdunarodnom biznese]. (in Russian). - SPb .: Polytechnic Publishing House. un-that

Kostin K.B. (2018) Foresight of the Global Digital Trends, Strategic management, 23 (1), 11-19. https://doi.org/10.5937/StraMan1801011K

Landing - what it is +12 tips for creating a landing page in examples. [Lending - chto eto takoe +12 sovetov po sozdaniyu landing page $v$ primerah] (in Russian), (2019). Retrieved September 13, 2019 from https://vk.com/@vk_business_idea-lending-chto-etotakoe-12-sovetov-po-sozdaniu-landing-page-v

Lizunkov V.G., Policinskaya E.V., SHutova T.A., \& Trifonov V.A. (2018) Analysis of economic Indexes of the EURASEC tegration Association [Analiz ekonomicheskih pokazatelej integracionnogo ob"edineniya EVRAZES]. Fundamental research. (in Russian), 1, 81-86. https://doi.org/10.17513/fr.42053

\section{$\bowtie$ Correspondence}

\section{Konstantin B. Kostin}

Saint-Petersburg State University of Economics Sadovaya str. 21, office 2094 St. Petersburg 191023, Russia E-mail: kost_kos@mail.ru
Measuring the Information Society Report (2017), 1. ITU Retrieved September 13, 2019 from https://www.itu.int/en/ITUD/Statistics/Documents/publications/misr2017/MISR201 7_Volume1.pdf

Miller A., \& Miller M. (2019) Study of the problems of technological integration in the manufacturing industry in Russia, Strategic management, 24 (3), 33-42. https://doi.org/10.5937/StraMan1903033M

Nica, E. (2018). Gig-based working arrangements: Business patterns, labor-management practices, and regulations. Economics, Management, and Financial Markets, 13(1), 100-105. https://doi.org/10.22381/EMFM13120185

Pazizina K.V., \& Uniyat A.V. (2011) International economy: integration aspect [Mizhnarodna ekonomika: integracijni aspekti]. (in Ukrainian). Retrieved September 13, 2019 from

http://dspace.tneu.edu.ua/bitstream/316497/588/1/book. PDF

Philosophy of the integrations (2011) [Filosofiya integraciii] (in Ukraine) Monografiya / Za zag. red. V.D.Bondarenka, F.G.Vashchuka. - Uzhgorod: ZakDU,(Seriya «Evrointegraciya: ukraïns'kij vimir»), 18.

Popescu, G. H. (2018). Participation in the sharing economy: Labor, exchange, and consumption. An empirical analysis. Journal of Self-Governance and Management Economics, 6(1), 122-127. https://doi.org/10.22381/JSME6120185

Rosamond, B. (2000) Theories of European Integration, 58-72.

Service exports (2018). The data of the World Bank. Retrieved September 13, 2019 from https://data.worldbank.org/Index/BX.GSR.NFSV.CD?en $d=2017 \&$ start $=2017 \&$ view $=$ chart

Service imports (2018). The data of the World Bank. Retrieved September 13, 2019 from https://data.worldbank.org/Index/BM.GSR.NFSV.CD?en $d=2017$ \&start $=2017$ \&view $=$ chart

Sudarević T., Marić D. (2018). Global brands in the digital era. Anali Ekonomskog fakulteta u Subotici. 89-98. https://doi.org/10.5937/AnEkSub1839089S 